\title{
Chemical Composition, Nutritional Quality and Anti-Nutritional Factors of Weaning Food Prepared From Maize and Legumes
}

\author{
Tesby Mohamed Rashad Lotfy, Asteer Victor Abd Elnoor, Marwa Zaki Mahfouz, Asmaa Khaled Shafik ${ }^{1}$
}

\begin{abstract}
Weaning is a gradual process of introducing solid foods to infant's diet, alongside breast milk from the age of six months, since the breast feeding along cannot meet the infant nutritional requirement. This study aims to prepared high quality weaning foods from locally available raw materials at low cost. Weaning food was produced from the blends of yellow maize flour with some legumes (soybean, chickpeas and peanut). blends were prepared in a mixed ratio $70: 30$ using traditional techniques like milling, roasting and drying were evaluated. In samples, chemical composition, anti-nutritional factors, protein digestibility, amino acid content and sensory evaluation were determined. Results showed that the formulated weaning food. The maize used in this experiment were yellow maize of local variety. The results revealed that, the protein content ranged from $12.26 \%-17.68 \%$ of the weaning food blends from yellow maize is similarly close to the recommended daily intake for infants $(6$ month to 2 year) compared to the raw maize without legumes. The low moisture contents $(4.10 \%),(4.89 \%)$ and $4.72 \%$ in maize/ soybean, maize/chickpea and maize/peanut exhibited by the weaning food blends might give a good storage stability. The results of anti-nutrition factors ranges phytic acid (4.81 mg/100 g - $6.25 \mathrm{mg} / 100 \mathrm{~g})$, Trypsin inhibitor (0.46 TIU/100 $\mathrm{g}-0.52 \mathrm{TIU} / 100 \mathrm{~g})$ and tannins $(55.75 \mathrm{mg} / 100 \mathrm{~g}-$ $63.89 \mathrm{mg} / 100 \mathrm{~g})$
\end{abstract}

Heat treatment of grains resulted in low levels of phytic acid and higher in vitro protein digestibility ranged from $75.43 \%$ to $81.76 \%$ of the weaning feed mixtures,. Results on sensory evaluation showed that the best blend was contained maize/chickpeas then maize peanut but maize soybean and control lower acceptability.

Keywords: Roasted yellow maize; soybean; peanut; chickpeas; chemical composition; Protein digestibility; anti-nutritional factors and sensory evaluation.

\section{INTRODUCTION}

Breastfeeding encourages acceptance of new foods because of exposure to specific aromatic compounds. Given the sensory benefit of breastfeeding and the potential long-term effects of some breastfeeding experiences on subsequent feeding outcomes, the promotion of a varied and healthy diet during pregnancy and lactation will be beneficial for the future baby. Early learning of flavor through breastfeeding can confer an advantage on the infant through early exposure to healthy foods provided that the mother has a healthy diet
(Cooke and Fildes, 2011 and Forestell and Mennella, 2007).

Weaning food plays a vital role in children's overall growth, development and mental health (Sheriff 2015). Babies need complementary food-balanced foods, as well as breast milk, due to increased dietary needs of the growing body (Sajilata et al., 2002 and Umeta et al., 2003).

Cereals, the main source of calories in the South Asian diet, are sufficient in methionine and cysteine, a good source of complex B vitamins, (Gulzar, 2011). Cereals are deficient in lysine but have sufficient amino acids containing sulfur that are limited in legumes (Concon, 1975; Iqbal et al., 2006 and Tsai et al., 1975). While legumes are rich in lysine, the effects of supplements are very useful, as the nutritional value of the product is also improved (Amankwah et al., 2009).

Legumes are one of the highest crops contains protein, carbohydrate, dietary fiber and minerals (Tharanathan and Mahadevamma, 2003). They are an excellent source of protein and the essential amino acid lysine but are restricted in amino acids containing sulfur.

There is a need to make the most of the cheap cereals and legumes available to formulate weaning foods that are low in viscosity, high in price density and sufficient in the necessary nutrients (Okafor et al., 2012). The protein quality of the grain mixture improves because of the essential amino acids, methionine and cysteine contributed by the grains. In addition to the nutritional values of cereals and legumes, their use is limited due to the presence of anti-nutritional factors. Thus, reducing the use of food and growth in children.

It is therefore recommended that, when preparing complementary foods for children various methods should be used to inactivate and/or reduce these antinutritional factors these methods include roasting, soaking and cooking (Asma et al., 2006 and Magoha et al., 2014).

In this work the development of weaning foods with high protein content, high energy density and high digestibility were prepared from locally sources and low-cost raw materials is of vital importance, especially in developing countries. 


\section{MATERIALS AND METHODS}

\section{Materials}

Samples of yellow maize, soybean, peanut and chick pea were obtained from the local market, Alexandria, Egypt. The seeds were kept at room temperature in air tight containers.

\section{Methods}

\section{Preparation of yellow maize}

Maize grains were sorted to remove all extraneous materials. The clean yellow maize grains were separately washed in clean tap water. The grains were air dried for $12 \mathrm{~h}$. The dried grains were toasted for 30 min in an oven at $370^{\circ} \mathrm{C}$. The toasted grains were milled, using attrition mill, to fine particles, sieved, packaged and stored at room temperature $37^{\circ} \mathrm{C}$ for further analysis. (Isaac and Koleosho, 2012).

\section{Preparation of soybean flour}

Soybeans were thoroughly sorted to remove all extraneous materials. Soybeans were soaked in tap water for $6 \mathrm{~h}$ and washed several times with more water. It was then toasted in an oven at $370^{\circ} \mathrm{C}$ for $30 \mathrm{~min}$. (Soaking and roasting were intended to remove the beany flavor). and the roasted soybeans were then dehulled, followed by milling and sieving. The flour was then packaged and stored at room temperature for further analysis (Isaac and Koleosho, 2012).

\section{Preparation of Chickpea}

Chickpeas were manually cleaned to remove debris. Splited and discoloured seeds were discarded. Chick pea was also roasted in an oven at $370^{\circ} \mathrm{C}$ for $30 \mathrm{~min}$ and the seed coat was removed to get clean partially roasted chickpea (Isaac and Koleosho, 2012). Chickpea was milled, using attrition mill, to fine particle, sieved, packaged and stored at room temperature for further analysis.

\section{Preparation of peanut}

Peanut was manually cleaned to remove debris. Split and discoloured seeds were discarded. Peanuts were also roasted in an oven at $370^{\circ} \mathrm{C}$ for $30 \mathrm{~min}$ and the seed coat was removed to get clean partially roasted peanuts (Adenuga. 2010). The peanut was milled, using attrition mill, to fine particle, sieved, packaged and stored at room temperature for further analysis.

\section{Formulation of the weaning meals}

Weaning meals were formulated using yellow maize (soybean, peanut and chick pea) respectively in a 70:30 ratio, that is, $70 \%$ yellow maize: $30 \%$ (soybean, peanut and chick peas).

\section{Weaning foods formulation}

Weaning blends were formulated in $70 \%$ cereal to $30 \%$ legume ratios. Cooked blends (gruels) were prepared an initial flour paste was made mixing $100 \mathrm{~g}$ of flour cereal with legumes and $200 \mathrm{~mL}$ of deionized water. To the paste, $700 \mathrm{~mL}$ of boiling 30 deionized water was added and mixed well. Flour-water slurries were cooked in a boiling water bath until the temperature reached $95^{\circ} \mathrm{C}$. Cooking was continued an additional $15 \mathrm{~min}$ with stirring every $5 \mathrm{~min}$. Gruel temperature was recorded at 5-min intervals to ensure standardized cooking procedures (Griffith et al, 1998).

The result obtained to gruels soft and acceptability color, then the samples were dried before analysis .

\section{Sensory evaluation}

The sensory characteristics were evaluated by mothers in health offices and children from the age of 6 months according to( Hooda and Jood, 2005). The evaluated characteristics included colour, odour, texture, flavour and the overall acceptability. The 9- point hedonic scale with a scale ranging from 1 (Extremely dislike) to 9 (Extremely like) was used to evaluate the sensory attributes.

\section{Chemical analysis}

The proximate chemical composition including moisture, crude protein, crude fat, Crude fibers, ash and Nitrogen free extract (NFE) of weaning foods were analyzed according to (AOAC, 2007).

Caloric values were calculated from the sum of the percentages of crude protein and total carbohydrates multiplied by a factor of $4(\mathrm{Kcal} / \mathrm{g})$ plus the crude fat content multiplied by 9 (Kcal/g) according to (Zambrano et al., 2004)

\section{Minerals}

$\mathrm{Fe}, \mathrm{Ca}, \mathrm{Mg}$ and $\mathrm{Zn}$, were determined using Atomic Absorption Spectrophotometer (Shimadzu model AA6650) as described in AOAC Official Methods with (AOAC, 2007)

\section{Amino acid composition}

Determination of amino acid contents of the prepared weaning meals was done at Regional Center for Food and Feed, Cairo, Egypt by using amino acid analyzer (biochrom30) according to (Otter, 2012). The nutritive value of the protein was estimated by comparing the amino acid pattern of each product with FAO

\subsection{Determination of anti-nutritional factors}

Trypsin inhibitors were extracted and determined according to Hamerstrand et al. (1981) was used to determine qualitatively and quantitatively the presence of, Tannin was determined according to (Ahmed et al., 
2006) and phytate was determined according to (Davies and Reid 1979)

\section{1.a.Determination of Trypsin Inhibitor Activity}

Trypsin inhibitor (TrI) was extracted and determined according to (Hamerstrand et al, 1981). A sample (1.00 g) was extracted with $50 \mathrm{ml}$ of $(0.01 \mathrm{~N}) \mathrm{NaOH}$ (the $\mathrm{pH}$ adjusted, when required, to 8.4-10.0) for $3 \mathrm{hr}$. Stirring sufficient to keep the sample in suspension was maintained. This suspension was then diluted so that 2 $\mathrm{mL}$ of the sample extract inhibited $40-60 \%$ of the trypsin used as a standard in the analysis. The appropriate dilutions were determined from either a pre-knowledge of the heat treatment of the sample or from a urease analysis, which reflects the heat treatment of the sample. If the value obtained did not fall within the specified range of inhibition, the analysis was repeated with the correct dilution. To each of four test tubes, $2-\mathrm{mL}$ aliquots of the diluted sample extract were added with a wide-tip pipette. A fifth tube was prepared for the trypsin standard by adding $2 \mathrm{~mL}$ of distilled water. To three of the four tubes containing the sample extract and the tube containing distilled water, $2 \mathrm{~mL}$ of the trypsin solution was added, and the tubes were placed in a constant temperature bath $\left(37^{\circ} \mathrm{C}\right)$ for $10 \mathrm{~min}$. Five milliliters of BAPA solution (pre-warmed to $37^{\circ} \mathrm{C}$ ) was rapidly blown into each tube. The contents were stirred immediately on a vortex mixer, and the tubes were replaced in the constant temperature bath. The reaction was terminated exactly $10 \mathrm{~min}$ later by blowing in $1 \mathrm{~mL}$ of $30 \%$ acetic acid with immediate mixing with a vortex mixer. A sample blank (the fourth tube containing sample extract) was prepared by the same procedure except that the trypsin solution was added after the reaction was terminated by the addition of acetic acid. The absorbance of each solution was determined at 410 $\mathrm{nm}$ against the sample blank using (spectrophotometer). Values obtained from each of the three sample extracts were subtracted from the trypsin standard. These values were averaged, and the trypsin inhibitor content was determined from the following equation (2):

$\operatorname{TrI}(\mathrm{mg} / \mathrm{g}$ sample $)=\frac{\triangle O D}{0.019 \times 1000} \times$ dilution factor

\section{Measurement of tannin}

Tannin content of each blend was measured by the modified vanillin-hydrochloric acid method (Price and Butler 1978). Here, $0.2 \mathrm{~g}$ of dried sample were extracted with $1 \% \mathrm{HCl}$ in methanol for $20 \mathrm{~min}$. at $30^{\circ} \mathrm{C}$ and the product centrifuged using an Eagle Model 20 centrifuge. To $1 \mathrm{ml}$ of the extract, $5 \mathrm{ml}$ of vanillin reagent was added. The reaction mixture was left for $20 \mathrm{~min}$. at $30 \mathrm{C}^{\circ}$ after which the absorbance was read at $500 \mathrm{~nm}$ against a blank using a spectrophotometer. The blank contained $4 \% \mathrm{HCl}$ in methanol. Tannin concentration in $\mathrm{mg} / \mathrm{g}$ was extrapolated from a standard curve using (spectrophotometer). Values were converted to $\mathrm{mg} / 100 \mathrm{~g}$ using the formula equation (3):

Tannin content $(\mathrm{mg} / \mathrm{g})=$

$$
\frac{O D_{\text {soo }} \text { voli of extract }}{\text { slope weight of sample }} \text {. }
$$

\section{Determination of phytic acid}

Phytic acid was determined following the procedure of Davies and Reid (1979). One gram (1 g) of sample was extracted in $40 \mathrm{ml}$ of $0.5 \mathrm{M}$ nitric acid for $1 \mathrm{~h}$. The sample was filtered and $5 \mathrm{ml}$ of $0.08 \mathrm{M}$ ferric chloride was added. It was then boiled for $20 \mathrm{~min}$ and then filtered. The free iron (Fe3-) remaining in the solution was then determined calorimetrically by adding $2 \mathrm{ml}$ of $0.005 \mathrm{M}$ ammonium thiocyanate and the iron-binding capacities of the extracts was determined by difference using spectrophotometer. The results were then expressed in terms of $\mathrm{mg} \mathrm{Fe}$ bound $\mathrm{g}-1$ sample extracted.

\section{Determination of Protein digestibility}

protein digestibility was determined using enzymatic hydrolysis (pepsin and pancreatin), then the nitrogen contents were analyzed by the micro-kjeldahl method. The protein digestibility of samples was calculated by subtracting undigested protein from crude protein of the blends (Prakash and Prakash, 1999).

\section{Statistical analysis}

The statistical analysis was performed using the SPSS 25.0 software (Statistical Package for Social Sciences, USA). Analysis of variance (ANOVA) of the data was conducted and means property values were separated $(p \leq 0.05)$ with LSD test for the property values. Differences were considered significant at $\mathrm{p} \leq$ 0.05 .

\section{RESULTS AND DISCUSSION}

\section{Sensory properties}

The sensory evaluation was studied by children from 6 months to 2 years, as well as by mothers $(n=50)$ in nurseries and health offices. The data of sensory evaluation were presented in Table (1). The data showed that there were significant differences $(p \leq 0.05)$ between the weaning foods prepared in colour, texture, taste and overall acceptability. Generally, all formulated samples were significantly $(\mathrm{p} \leq 0.05)$ accepted for all the sensory properties. The best blend was that contained maize/chickpea followed by maize/peanut while maize/soybean was less acceptable comparing with the other blends. 
Table 1. Sensory evaluation of maize / legumes blends.

\begin{tabular}{lccccc}
\hline Blends & Colour & Odour & Texture & Taste & Over all acceptabilitv \\
\hline Control Maize & $2.01^{\mathrm{c}} \pm 0.87$ & $2.16^{\mathrm{c}} \pm 0.78$ & $3.25^{\mathrm{c}} \pm 0.68$ & $3.09^{\mathrm{c}} \pm 0.54$ & $3.90^{\mathrm{c}} \pm 0.72$ \\
Maize/Soybean & $2.12^{\mathrm{c}} \pm 1.19$ & $2.64^{\mathrm{c}} \pm 0.92$ & $3.48^{\mathrm{c}} \pm 0.68$ & $3.92^{\mathrm{c}} \pm 0.85$ & $4.08^{\mathrm{c}} \pm 0.85$ \\
Maize/Peanut & $5.0^{\mathrm{b}} \pm 1.01$ & $5.32^{\mathrm{b}} \pm 0.79$ & $6.02^{\mathrm{b}} \pm 0.68$ & $6.90^{\mathrm{b}} \pm 0.79$ & $7.20^{\mathrm{b}} \pm 0.95$ \\
Maize/chickpeas & $6.98^{\mathrm{a}} \pm 1.06$ & $7.20^{\mathrm{a}} \pm 1.03$ & $7.84^{\mathrm{a}} \pm 0.68$ & $8.84^{\mathrm{a}} \pm 0.68$ & $8.80^{\mathrm{a}} \pm 0.68$ \\
\hline
\end{tabular}

Values are mean of 50 replicates and are given as mean \pm standard error. Different letters in the same row indicate significant differences according to LSD test $(\mathrm{P} \leq 0.05)$.

\section{Proximate chemical composition and mineral content.}

The data of the proximate composition analysis of these blends are presented in Tables (2). Also, the mineral contents of these blends are presented in Tables (3).

Table (2) the chemical analysis of the yellow maize mixtures showed that the lowest percentage of moisture was in the yellow maize mixture with peanuts $(4.10 \%)$ The highest percentage of moisture was in the Control $(8.15 \%)$, and the highest percentage of protein was in the yellow maize mixture with soybeans $(17.68 \%)$ While the lowest protein ratio was the Control $(12.26 \%)$, the highest ash rate was in the yellow maize mixture with soybeans $(4.81 \%)$ and the lowest rate of ash was in the Control $(2.24 \%)$, the highest percentage of fat was in the yellow maize mixture with peanuts $(18.09 \%)$ and the lowest percentage of fat was in the mixture of yellow maize with soybeans $(10.10 \%)$, the highest percentage of carbohydrates were in the maize chickpeas $(63.11 \%)$ while the lowest carbohydrate ratio was in the yellow maize mixture with peanuts (55.92\%), the highest percentage of calories was in the mixture of yellow maize with peanuts $(457.4 \mathrm{kcal})$ while the lowest percentage of calories was in the mixture of yellow maize with soybeans $(397.9 \mathrm{kcal})$.

Ali et al.(2017) prepared maize- chickpea extrudes and they found that the ratio of ingredients in the optimized weaning mix was $40 \%$ maize- chickpea extrudes, $35 \%$ skim milk powder, and $25 \%$ sugar (w/w). The nutrient content are agreement with the standards described by PFA (Tripathi et al., 2007) with high protein and starch digestibility.

Analysis of minerals for yellow maize mixtures (Table 3) showed that the highest percentage of calcium in yellow maize with soy $(1.09 \%)$ and the lowest percentage of calcium was in maize with chickpeas $(0.21 \%)$, the highest percentage of iron was in yellow maize with soya (4.79\%), the lowest percentage of iron was in Control $(1.56 \%)$, the highest percentage of magnesium was in Control (37.10\%), the lowest percentage of magnesium was in yellow maize with chickpeas $(7.74 \%)$, the highest percentage of zinc was in maize with soya $(0.94 \%)$ and the lowest percentage was in the control $(0.19 \%)$. The minerals results are in agreement with Sheriff (2015) where the increase in the $\mathrm{Mg}(19.3 \pm 0.02) \mathrm{Zn}(0.45 \pm 0.02)$ and $\mathrm{Fe}(1.04 \pm 0.01)$ levels of the weaning food blend. Low level of calcium $(0.76 \pm 0.02)$ and sodium was recorded.

\section{Anti-nutritional factors}

Anti-nutrition factors including Phytic acid, Tannins and Trypsin inhibitors are presented in Table (4). Phytic acid in the formulated weaning food ranged from 4.52 to $6.25 \mathrm{mg} / 100 \mathrm{~g}$. The maize/soybean blend had the highest value of $6.25 \mathrm{mg} / \mathrm{g}$.

Table 2. Chemical composition of formulated weaning foods

\begin{tabular}{lcccc} 
Component \% & $\begin{array}{c}\text { Control } \\
\text { Maize }\end{array}$ & Maize/ Soybeans & Maize/ Peanuts & Maize/ Chickpea \\
\hline Moisture & $8.15^{\mathrm{ab}} \pm 5.65$ & $4.72^{\mathrm{c}} \pm 0.15$ & $4.10^{\mathrm{d}} \pm 0.22$ & $4.89^{\mathrm{cd}} \pm 0.20$ \\
Protein & $12.26^{\mathrm{b}} \pm 0.13$ & $17.68^{\mathrm{a}} \pm 0.31$ & $14.53^{\mathrm{c}} \pm 0.09$ & $16.34^{\mathrm{b}} \pm 0.07$ \\
Ash & $2.24^{\mathrm{b}} \pm 0.07$ & $4.81^{\mathrm{a}} \pm 0.07$ & $4.61^{\mathrm{c}} \pm 0.10$ & $2.77^{\mathrm{b}} \pm 0.09$ \\
Fibers & $2.11^{\mathrm{b}} \pm 0.02$ & $2.29^{\mathrm{b}} \pm 0.06$ & $2.75^{\mathrm{a}} \pm 0.26$ & $2.69^{\mathrm{a}} \pm 0.30$ \\
Fats & $13.16^{\mathrm{a}} \pm 0.01$ & $10.10^{\mathrm{d}} \pm 0.17$ & $18.09^{\mathrm{a}} \pm 0.31$ & $10.20^{\mathrm{d}} \pm 0.20$ \\
Carbohydrates* & $62.08^{\mathrm{bc}} \pm 0.06$ & $60.40^{\mathrm{bc}} \pm 0.09$ & $55.92^{\mathrm{bc}} \pm 0.01$ & $63.11^{\mathrm{bc}} \pm 0.02$ \\
Calories & $405.3^{\mathrm{c}} \pm 0.01$ & $397.9^{\mathrm{e}} \pm 0.01$ & $457.4^{\mathrm{a}} \pm 0.01$ & $414.4^{\mathrm{b}} \pm 0.01$ \\
\hline
\end{tabular}

*Calculated by the difference

Values are mean of three replicates and are given as mean \pm standard error. Different letters in the same row indicate significant differences according to LSD test $(\mathrm{P} \leq 0.05)$. 
Table 3. Mineral contents of the weaning food cereal- legumes blends

\begin{tabular}{|c|c|c|c|c|}
\hline Mineral (mg/g) & $\begin{array}{c}\text { Control } \\
\text { Maize }\end{array}$ & Maize/ Soybeans & Maize/ Peanuts & Maize/ Chickpeas \\
\hline$\overline{\mathrm{Ca}}$ & $0.42^{\mathrm{d}} \pm 0.01$ & $1.09^{\mathrm{ab}} \pm 0.12$ & $0.72^{\mathrm{c}} \pm 0.17$ & $0.21^{\mathrm{e}} \pm 0.11$ \\
\hline $\mathrm{Fe}$ & $1.56^{\mathrm{e}} \pm 0.01$ & $4.79^{\mathrm{a}} \pm 0.16$ & $1.94^{\mathrm{d}} \pm 0.13$ & $2.77^{b} \pm 0.16$ \\
\hline $\mathrm{Mg}$ & $37.10^{\mathrm{a}} \pm 0.01$ & $18.90^{\mathrm{b}} \pm 0.16$ & $10.87^{\mathrm{d}} \pm 0.24$ & $7.74^{\mathrm{g}} \pm 0.27$ \\
\hline $\mathrm{Zn}$ & $0.19^{c} \pm 0.01$ & $0.94^{\mathrm{a}} \pm 0.16$ & $0.61^{\mathrm{b}} \pm 0.10$ & $0.74^{\mathrm{ab}} \pm 0.27$ \\
\hline
\end{tabular}

Values are mean of three replicates and are given as mean \pm standard error. Different letters in the same row indicate significant differences according to LSD test $(\mathrm{P} \leq 0.05)$.

Table 4. Anti-nutritional factors and protein digestibility of formulated weaning foods:

\begin{tabular}{lcccc}
\hline \multirow{2}{*}{ Factors } & \multirow{2}{*}{ control maize } & \multicolumn{3}{c}{ Maize } \\
\cline { 2 - 4 } & & Chickpeas & Soybeans & Peanuts \\
\hline Phytic acid (mg/100g) & $4.60^{\mathrm{c}} \pm 0.07$ & $4.81^{\mathrm{b}} \pm 0.12$ & $6.25^{\mathrm{a}} \pm 0.05$ & $4.52^{\mathrm{c}} \pm 0.12$ \\
Tannins (mg/100g) & $57.70^{\mathrm{bc}} \pm 0.06$ & $60.78^{\mathrm{b}} \pm 0.03$ & $63.89^{\mathrm{a}} \pm 0.06$ & $55.75^{\mathrm{c}} \pm 0.03$ \\
Trypsin inhibitor (TIU/mg) & $0.47^{\mathrm{b}} \pm 0.02$ & $0.48^{\mathrm{a}} \pm 0.03$ & $0.52^{\mathrm{a}} \pm 0.02$ & $0.46^{\mathrm{b}} \pm 0.02$ \\
Protein digestibility $(\%)$ & $75.90^{\mathrm{c}} \pm 0.05$ & $81.76^{\mathrm{b}} \pm 0.02$ & $78.77^{\mathrm{bc}} \pm 0.05$ & $75.34^{\mathrm{c}} \pm 0.05$ \\
\hline V
\end{tabular}

Values are mean of three replicates and are given as mean \pm standard error. Different letters in the same row indicate significant differences according to LSD test $(\mathrm{P} \leq 0.05)$.

However, there is no clear significant difference between the other blends. Roasting of legumes reduced the phytic acid. The inherent phytase activity on cereals is believed to be activated during treatment (Sharma $e t$ $a l, .2018$ ). On the other hand, (Embaby, 2010) reported that phytic acid content is unaffected or increased after heat treatments.

Trypsin inhibitors are heat labile and can be partially and completely denatured when exposed to elevated temperature. The value of Trypsin inhibitors in the formulated weaning food is varied between 0.46 to 0.52 these low values are mainly due to cooking and roasting processes. Wang et al,. (1997) reported that the skin vapor of cowpea resulted in a greater reduction in trypsin inhibitor activity than the use of water blanching. However, Hernandez-Infante et al,. (1998) reported that microwave cooking destroyed trypsin inhibitors to a degree similar to those observed in six legumes cooked using the traditional methods. Total tannins in the formulated weaning food varied from 55.75 to 63.89 $\mathrm{mg} / 100 \mathrm{~g}$ as shown in table(4), legumes had a low tannin content than maize. In legume, most tannins are located in seed coats (skin) and hulls are practically tannin free (Naczk and Shahidi, 2004).

The low content of tannins during roasting process may be due to the loss of compounds during treatment at high temperature (Nithya et al., 2007). Also the loss of tannins may be due to degradation or interaction with other components of seeds, such as proteins, to form insoluble complexes (Embaby, 2010). Osman (2007) reported a significant increase in tannin content in cooked, autoclaved and roasted Dolichols lablab bean. Additionally, Embaby (2010) found that autoclaving, ordinary cooking and microwave cooking didn't affect tannin content in bitter lupin seeds.

Protein is an indissoluble ingredient in the human diet. Without proteins, cells will not be able to function properly, and organs and tissues will not be able to perform their duties, and the bodies will vanish. There are many sources of protein available to children. FAO/WHO has adopted a protein-corrected amino acid, as the preferred method of measuring the value of protein in human nutrition (Hulse 1989; Ling et al., 1961 and Wondimu and Malleshi, 1996).

The protein digestibility in vitro of the formulated weaning foods was varied between $75.34 \%$ for maize/peanut blend to $81.76 \%$ for maize/chickpea blend. The studied formulated weaning blends had good digestibility because their values were high than $75 \%$.

\section{Amino acid composition}

Analysis of amino acids in the formulated weaning foods showed that the protein contain nutritionally beneficial amounts of most essential amino acids but they contain low levels of amino acids containing sulfur. The essential amino acid found were threonine, lysine, valine, methionine, isoleucine, leucine, phenylalanine and histidine (Table 5). While the non-essential amino acids were aspartic, arginine, serine, proline, glutamic, cystine, glycine, alanine and tyrosine also was showed in (Table 5).

The results indicated that Lucien varied from 1.27 to $1.67 \%$, while methionine was the lowest essential amino acids presented in the study and varied from 0.2 to $0.39 \%$, 
Table 5. Amino acid composition of formulated weaning foods

\begin{tabular}{lcccc}
\hline Amino acids & $\begin{array}{c}\text { Control } \\
\text { Maize }\end{array}$ & Maize / soybeans & Maize /peanuts & Maize/ chickpeas \\
\hline Es/100g & g/100g & g/100g & g/100g \\
\hline Thrential amino acids & & & & \\
Lysine & 0.42 & 0.75 & 0.51 & 0.54 \\
Valine & 0.09 & 0.95 & 0.50 & 0.59 \\
Methionine & 0.55 & 0.90 & 0.77 & 0.70 \\
Cystine & 0.75 & 0.39 & 0.20 & 0.29 \\
Tyrosine & 0.57 & 0.56 & 0.30 & 0.22 \\
Isoleucine & 0.48 & 0.75 & 0.64 & 0.53 \\
Lucien & 0.53 & 0.82 & 0.54 & 0.49 \\
Phenylalanine & 1.08 & 1.67 & 1.39 & 1.27 \\
Histidine & 0.64 & 0.99 & 0.78 & 0.73 \\
Non-essential amino acids & 0.34 & 0.52 & 0.39 & 0.35 \\
Aspartic & & & 1.50 & 1.26 \\
Arginine & 1.20 & 1.95 & 1.18 & 1.30 \\
Serine & 0.94 & 1.20 & 0.66 & 0.69 \\
Proline & 0.53 & 0.79 & 1.0 & 1.50 \\
Glutamic & 0.80 & 1.26 & 2.80 & 3.34 \\
Glycine & 2.24 & 0.33 & 0.74 & 0.55 \\
Alanine & 0.59 & 0.83 & 1.11 & 0.94 \\
\hline
\end{tabular}

but the highest percentage of methionine was in control $0.75 \%$ because Cereals, the main source of carbohydrates, are adequate in methionine and cysteine.

The non-essential amino acids were found in a wide range. Glutamic acid was the most predominant nonessential amino acid found and ranged from 2.34 to $3.33 \%$, followed by aspartic acid which varied from 1.26 to $1.95 \%$. However, the serine was the lowest nonessential amino acid presented in the study and varied from 0.66 to $0.79 \%$.

The essential amino acids were found lower than FAO references 5.8, 6.6, 2.8, 3.4, 1.9, 3.5, 2.5, and $6.3 \%$ for Lysine, Leucine, Isoleucine, Therionine, Histidine, Valine, Methionine Cysteine and Phenylalanine Tyrosine, respectively (FAO, 2001).

\section{CONCLUSION}

The weaning formulations in the present study are based on commonly consumed, low-cost food materials locally-available in market. There is need to have maximum utilization of commonly available cheap cereals and legumes such as yellow maize, soybean, peanuts and chickpea to formulate weaning foods that would be low in viscosity high in caloric density and adequate in necessary nutrient. The protein content of the weaning food blends ranged from (7.90 -17.68) and is better than the control. There is an increase in vitro protein digestibility in the weaning food blends, and this is as a result of reduction in the level of anti-nutritional factor in the raw grains during formation.

Infants and young children are at an increased risk of malnutrition from six months of age onwards, when breast milk alone is no longer sufficient to meet all their nutritional requirements, complementary feeding should be started. Initiating complementary feeds too early or too late can lead to malnutrition. Poor quality of weaning foods and improper weaning practices predispose infants to malnutrition, growth retardation, infection, diseases and high mortality.

\section{RECOMMENDATIONS}

- It is recommended that infants feed on this formulation be breast feed for at least 2 years, as the formulation is intended to act as supplement to breast milk.

- It is recommended that weaning foods be introduced gradually and in small quantities to child.

- It is recommended mixing cereals with legumes because cereals such as maize, the main source of calories in the diet, are adequate in methionine and a good source of B-complex vitamins while legumes such as soy bean, peanut and chick peas are rich in lysine.

- It is recommended to cook, soak and roasting cereals and legumes to reduce the anti-nutritional factor and increase protein digestibility. 


\section{REFRERENCES}

Adenuga,W . 2010.Nutritional and sensory profiles of sweet potato based infant weaning food fortified with cowpea and peanut. Journal of Food Technology 8(5):223-228

Ahmed, M.B., R.A.Hamed, M.E.Ali, A.B.Hassan and E.E.Babiker.2006.Proximate composition, antinutritional factors and protein fractions of guar gum seeds as influenced by processing treatments. Pakistan Journal of Nutrition 5(5):481-484

Ali, S., B.Singh and S.Sharma. 2017.Response surface analysis and extrusion process optimisation of maizemungbean-based instant weaning food. International Journal of Food Science \& Technology 51(10):2301-2312

Amankwah, E., J. Barimah, A.Nuamah, J.Oldham, C.Nnaji and P. Knust. 2009. Formulation of weaning food from fermented maize, rice, soybean and fishmeal. Pakistan Journal of Nutrition 8(11):1747-1752

AOAC.2007. Determination of fat, moisture, and protein in meat and meat products by using the FOSS FoodScan near-infrared spectrophotometer with FOSS artificial neural network calibration model and associated database: collaborative study. Journal of AOAC International 90(4):1073-1083

Asma, M.A., E.B. El Fadil and A.H.El Tinay. 2006. Development of weaning food from sorghum supplemented with legumes and oil seeds. Food and Nutrition Bulletin 27(1):26-34

Concon, J.M.1975. Rapid method for the determination of lysine in cereal grains without hydrolysis. Analytical biochemistry 66(2):460-480

Cooke, L., A.Fildes.2011.The impact of flavour exposure in utero and during milk feeding on food acceptance at weaning and beyond. Appetite 57(3):808-811

Davies, N. and H. Reid.1979. An evaluation of the phytate, zinc, copper, iron and manganese contents of, and $\mathrm{Zn}$ availability from, soya-based textured-vegetable-protein meat-substitutes or meat-extenders. British Journal of Nutrition 41(3):579-589

Embaby, H.E-S. 2010.Effect of soaking, dehulling, and cooking methods on certain antinutrients and in vitro protein digestibility of bitter and sweet lupin seeds. Food Science and Biotechnology 19(4):1055-1062

FAO.2001. Food and Agriculture Organization for theUnited Nation. Crop and food supply situation inSudan. Special report. FAO 7:1-16.

Forestell, C.A. and J.A.Mennella. 2007.Early determinants of fruit and vegetable acceptance. Pediatrics 120(6):12471254

Griffith, L., M.Castell-Perez and M. Griffith.1998.Effects of blend and processing method on the nutritional quality of weaning foods made from select cereals and legumes. Cereal chemistry 75(1):105-112.

Gulzar, M. 2011.Evaluation of weaning foods formulated from germinated wheat and mungbean from Bangladesh. African journal of food science 5(17):897-903

Hamdi, M., R. Nasri, N. Dridi, H. Moussa, L.Ashour and M.Nasri. 2018. Improvement of the quality and the shelf life of reduced-nitrites turkey meat sausages incorporated with carotenoproteins from blue crabs shells. Food Control 91:148-159
Hamerstrand, G., L.Black and J. Glover.1981. Main content area Trypsin inhibitors in soy products: modification of the standard analytical procedure. Cereal Chemistry 58(1):42-45

Hernandez-Infante, M., V. Sousa, I.Montalvo and E.Tena.1998. Impact of microwave heating on hemagglutinins, trypsin inhibitors and protein quality of selected legume seeds. Plant Foods for Human Nutrition 52(3): 199-208

Hooda, S. and S. Jood.2005.Organoleptic and nutritional evaluation of wheat biscuits supplemented with untreated and treated fenugreek flour. Food Chemistry 90(3):427435

Hulse, J. 1989. Nature, composition and utilization of grain legumes. Uses of tropical grain legumes. 27.(11).

Iqbal, A., I.A.Khalil, N.Ateeq and M.S. Khan.2006. Nutritional quality of important food legumes. Food chemistry 97(2):331-335.

Isaac, A.T. and Koleosho, A.2012. Effects of Processing Method on the Nutrients' Composition of Maize/Soya Complementary Food. J. Pharm. Biol. Sci 4(1):39-43

Ling, E., S.Kon and J. Porter.1961. The composition of milk and the nutritive value of its components. Milk: The mammary gland and its secretion 2:195-263.

Magoha, H., B. De Meulenaer, M.Kimanya, D. Hipolite, C. Lachat and P.Kolsteren.2014. Fumonisin B1 contamination in breast milk and its exposure in infants under 6 months of age in Rombo, Northern Tanzania. Food and chemical toxicology 74:112-116

Milán-Carrillom J . 2007. Nutritional properties of quality protein maize and chickpea extruded based weaning food. Plant foods for human nutrition 62(1):31

Naczk, M. and Shahidi, F. 2004.Extraction and analysis of phenolics in food. Journal of Chromatography A 1054(12):95-111

Okafor, J., G.Okafor, A.Ozumba and G. Elemo .2012. Quality characteristics of bread made from wheat and Nigerian oyster mushroom (Pleurotus plumonarius) powder. Pakistan Journal of Nutrition 11(1):5-10.

Omosebi, M.O., O.F. Osundahunsi and T.N.Fagbemi.2018. Effect of extrusion on protein quality, antinutritional factors, and digestibility of complementary diet from quality protein maize and soybean protein concentrate. Journal of Food Biochemistry:e12508

Osman, M.A. 2007. Effect of different processing methods, on nutrient composition, antinutrional factors, and in vitro protein digestibility of Dolichos lablab bean [Lablab purpuresus (L) Sweet]. Pakistan Journal of Nutrition 6(4):299-303

Otter, D.E. 2012. Standardised methods for amino acid analysis of food. British Journal of Nutrition 108(S2):S230-S237.

Price, M.L., S.Van Scoyoc and L.G. Butler.1978. A critical evaluation of the vanillin reaction as an assay for tannin in sorghum grain. Journal of Agricultural and Food Chemistry 26(5):1214-1218.

Prakash, V. and J. Prakash.1999.In vitro protein digestibility of legumes cooked with spices. Food/Nahrung 43(1):1921. 
Sajilata, G., R.S.Singhal and P.R. Kulkarni. 2002. Weaning foods: A review of the Indian experience. Food and nutrition bulletin 23(2):208-226.

Sharma, S., A.Singh, U. Sharma, R. Kumar and N.Yadav.2018.Effect of thermal processing on anti nutritional factors and in vitro bioavailability of minerals in desi and kabuli cultivars of chick pea grown in North India. Legume Research: An International Journal. 41.(2).

Sheriff ,M. 2015. Effects of Fortification of Rice with Banjara Beans and Sesame on Chemical Composition, Mineral Ele-ments and Vitamin Contents of a Complementary Meal. EC Nutrition 1:35-40.

Tharanathan, R. and S. Mahadevamma .2003. Grain legumes - a boon to human nutrition. Trends in Food Science \& Technology 14(12):507-518.

Tripathi , M., S.K. Khanna and M.Das.2007. Surveillance on use of synthetic colours in eatables vis a vis Prevention of Food Adulteration Act of India. Food Control 18(3):211219.
Tsai, C-Y., A. Dalby and R.Jones.1975.Lysine and tryptophan increases during germination of maize seed. Cereal Chemistry. 52:356-360.

Umeta, M., C.E. West, H.Verhoef , J. Haidar and J.G.Hautvast.2003. Factors associated with stunting in infants aged 5-11 months in the Dodota-Sire District, rural Ethiopia. The Journal of nutrition. 133(4):1064-1069

Wang, N., M. Lewis, J.Brennan and A. Westby .1997.Effect of processing methods on nutrients and anti-nutritional factors in cowpea. Food chemistry. 58(1-2):59-68.

Wondimu, A. and N.G.Malleshi. 1996. Development of weaning foods based on malted, popped, and roller-dried barley and chickpea. Food and Nutrition Bulletin-United Nations University. 17:169-176

Zambrano, F., P.Despinoy, R.Ormenese and E. Faria.2004.The use of guar and xanthan gums in the production of 'light'low fat cakes. International journal of food science \& technology 39(9):959-966. 
الملخص العربي

\section{التركيب الكيميائي، الجودة الغذائية والعوامل المضادة للتغذية لأغذية الفطام المعدة من الأرة والبقوليات}

تسبي محمد رشاد لطفي، اسنز فيكتور عبد النور، مروة زكي محفوظ، اسماء خالد شفيق

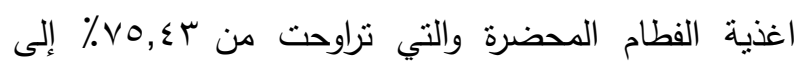

$\% \wedge 1, \vee \top$

وأظهرت نتائج التقييم الحسي أن أفضل خليط كان بحتوي على الذرة/ الحمص ثم الذرة الصفراء مع الفول السوداني ولكن كان معدل القبول اقل في خليط فول الصويا مع الذرة والكنترول.

أوضحت النتائج أن معظم المبحوثين كانوا من الثباب وأعمارهم أقل من ·r سنة، وأن ثلثنه يعانون من مشاكل صحية مرتبطة بالكبد والجهاز الهضمي والجهاز العصبي. قبل تطبيق البرنامج التثقيفي بلغت نسبة دن كان لديهر معلومات غذائية صحيحة هب\%، ومن لديهم اتجاهات

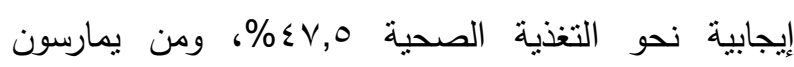
السلوك الغذائي الصحي 00\% فقط. بلغت ثلك النسب بعد

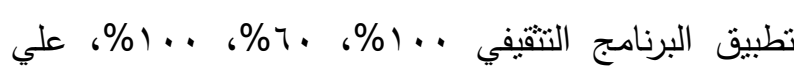
التوالي. أما برنامج التذخل الغذائي فقد أدي تطبيقه إلي حدوث تحسن في معظم المعايير التي تم قياسها للمرضي والتي شملت مؤشر كتلة الجسم، ووظائف الكبد والكلي، كما فيا فئي

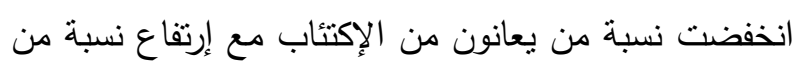

تحسنت حالتهم الصحية الوظيفية.

استخلصت الدراسة أن برامج التتقيف الغذائي و التدخل

الغذائي هامة جدا لعلاج المدمنين ويجب أن ثوجه للمرضي برامي بالتوازي مع العلاج الطبي والنفسي، وأن تطبق في المراحل الأولي للعلاج والتي تتمل إنسحاب المخدر، والتخلص من سموم الجسم والتأهيل لمساعدة الكبد وأجزة الجسم الأخري علي أداء وظائفها بكفاءة.
الفطام هو عملية تدريجية لإدخال الأطعدة الثبه صلبة إلى النظام الغذائي للرضيع، إلى جانب حليب الثي من عمر لإلى ستة أثهر، حيث أن الرضاعة الطبيعية لا يمكنها تلبية الاحتياجات الغذائية للرضيع. تهدف هذه الدراسة إلى إعداد

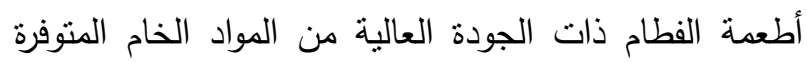
محليًا بتكلفة منخفضة. تم إنتاج طعام الفطام من خلطات طحين الذرة الصفراء مع بعض البقوليات (فول الصويا والحمص والفول السوداني). تم إعداد الخلطات بنسبة •r, • • باستخدام التقنيات التقليدية مثل الطحن والتحميص والتجفيف. في العينات، تم تقدير التركيب الكيميائي، والعوامل

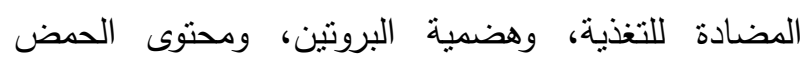
الأميني والتقييم الحسي.اظهرت النتائج أن اطعمة الفطام

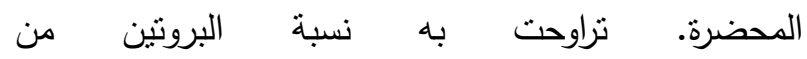

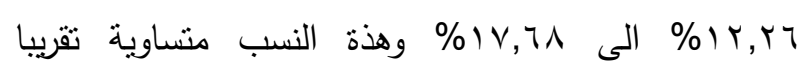
للمتتاول اليومي الموصى به للرضع (من 7 أشهر إلى سنة)

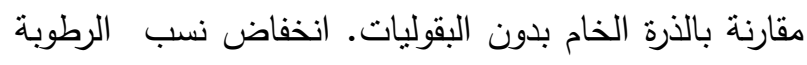

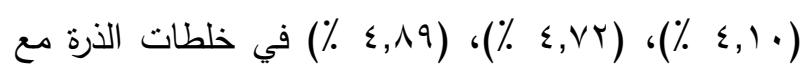

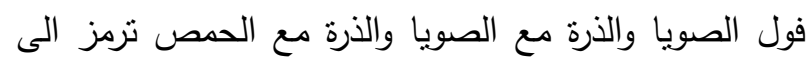

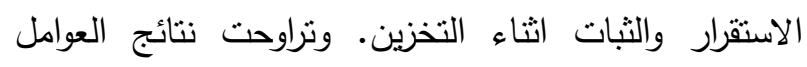

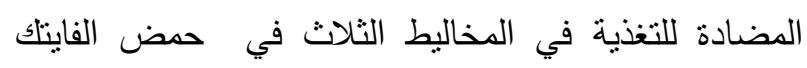

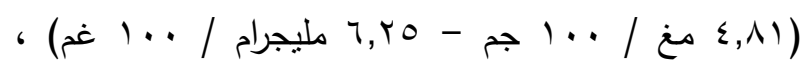

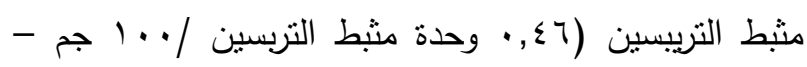

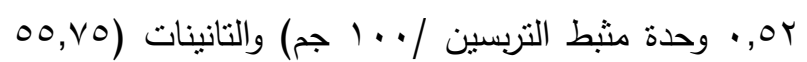

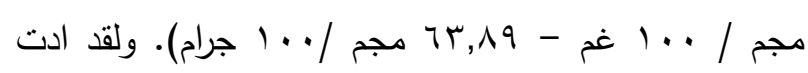
المعاملات الحرارية للحبوب قبل التحضير الى خفض نسب مضادات التغذية وبالتالي ارتفاع نسبة هضمية البروتين في 